\title{
Breaking the Bottleneck: Conflicts Metamorphosis of Chure Landscape Management in Federal Nepal
}

\author{
Bhola Bhattarai ${ }^{1}$, Dipak Bishwokarma ${ }^{2}$ and Mathilde Legras ${ }^{3}$ \\ ${ }^{1}$ National Forum for Advocacy Nepal, Kathmandu, Nepal, \\ ${ }^{2}$ Practical Action, South Asia Regional Office, Nepal and ${ }^{3}$ Agro Paris Tech, Paris, France \\ Corresponding author: bhola_bhattarai@hotmail.com
}

\begin{abstract}
Chure forests, which is one of the youngest and most fragile landscapes of Nepal, continue to be degraded due to resource exploitation and conflict over its management. This region is considered to be the lifeline to down-stream communities - mainly for water - while inhabiting millions of poor and rural people that depend on natural resources - especially forests commons. Government initiatives to manage Chure have escalated contestations in the recent years. Its decision to declare Chure landscape as 'Environmental Protection Area' manifests a protection-centric management approach. This research scrutinises the genesis of contestation on Chure management utilising three-elements of conflicts described by Brown et al. (2017). It analyses power-relation to demonstrate potential implications on Chure landscape management as well as conflict resolution options, in the changed political context of federal Nepal. Our research reveals that all stakeholders are well aware of the continuous degradation of Chure landscape and have agreed on discovering the common locus of sustainable management. However, the state-community contestation still persists due to divergent understandings of degradation. Despite multiple strands of management options, contextualised communitybased approach still appears to be an appropriate option to solve this persistent contestation, building on the practices of community forestry and historic failures of top-down, protectioncentric management practice. The newly elected provincial and local governments could further facilitate a more effective management of Chure landscape through resolving the contentious state-community conflict.
\end{abstract}

Key words: Chure management, conflict, conflict management, federal structure, local government

\section{INTRODUCTION}

The sustainable management of forest commons is nowadays a global and topical issue. Engagement of multiple actors, including the state and local communities, is evident in its management decision (Andersson and Ostrom 2008; Michon et al. 2013). However, such engagements have been broadly shaped by each actors own interest and legacy. The power dynamics among them determine the degree of their decisive role as an individual actor (Schusser et al. 2016). Each role is actually uneven as some hold more power than others and hence have a greater influence on policy and management process (Cilliers et al. 2013; Schusser et al. 2016). Ultimately, the governance system put in place, including political and policy changes, has an important role to play in the degree of stakeholders' decision-making. Such changes have direct implication on the role of local communities and hence on its contribution to their livelihood (Ratner et al. 2017). The evolution of roles and influence among actors alters the actorpower dynamics and may eventually lead to further contestation. 
The key elements of contestation over natural resources may include geographic location of the resources, different stakeholders engaging on resource management or decision making process, and its perceived consequences (Brown et al. 2017). In fact, the stakeholderseither individuals or groups constitute major element of contestation as they can have incompatible interests and unequal accessibility over certain resources. The countries with higher dependency on agricultural products and natural resources are prone to conflicts, as a result of either abundance or scarcity of those resources (Humphreys 2005). In a broader context, these arguments may be explained 'either by greed or grievances' such as feelings of social, economical or political marginalisation (Collier 2003). Its onset is primarily responsive to the alteration on the access and availability of resources and this long-standing issue will still be of great challenge for the future.

Forest resources in Nepal constitute a major part of local livelihoods as well as a regular source of national revenue, in addition to their significance on the overall ecosystem stability. There have been multiple interests in managing and utilising forest resources. In retrospect, forests in Nepal served as a major source of government revenue and hence were mostly captured by the State (Bhattarai et al. 2002; Ojha et al. 2007). It also used to be distributed to the local elites and loyalties as part of incentive - Jagir and Birta (Bhattarai et al. 2002; Banjade 2012), on the other hand, the local peasants were struggling to access the forest resources. The Private Nationalisation Act (1975) allowed the transfer of ownership and management of private forests to the national government.
The access to forest products then was restricted for local communities, which further alienated them. During then, deforestation became prevalent, leading to scarcity of forest products including fuelwood that were critical for livelihoods of the local people. Following the urgency, the issue dragged global attention. The warning of different scholarly works such as the theory of Himalayan degradation and international agencies for instance, led the government to delegate forest management authority to the Panchayats. However, that too did not solve the issue, since lack of access of local people to the forest resource persisted. The enforcement of the Master Plan for Forestry Sector (MPFS) 1989 and the promulgation of multi-party democratic system in 1990 served to create a conducive environment for decentralisation of decision making process in forestry. Gradually, community forestry became a popular programme and the handover of forests to local communities gained momentum following enactment of Forest Act (1993) and Forest Regulation (1995) (Ojha et al. 2007). These policies have been instrumental towards promoting handover of more than 22,000 community forests (CF) across the country. Despite its success, CF have often come under scrutiny by the government where decisions have attempted to suppress the rights, already devolved to the Community Forest User Groups (CFUGs). For instance, imposition of 40 per cent tax on sale of forest products, restriction in harvesting, collection, and distribution of green tress were some of the factors leading to contestations between CFUGs and the government. Among others, contestation between the government and CFs in Chure has gained wider attention due mainly to the 
fact that there has been several attempts from the government to amend certain policy provisions that would result in recentralisation of the authority.

The Chure region alone comprises of 14 per cent of the country's population and thus has a geo-political importance. Considering its ecological fragility and geo-political significance, the government initiated 'Chure Conservation Program' as the nation's priority initiative in 2014 . Building on the existing initiatives, Nepal government declared Chure landscape as an 'Environmental Protection Area (EPA)' and formulated the 'President Chure-Terai-Madesh Conservation Development Committee' (here after Chure Board) - an overarching body to manage Chure landscape including its forests in 2014 (Bishwokarma et al. 2016). The declaration of EPA and formation of the Chure board led to differences in opinion among the stakeholders and contestation between the government and local CFUGs. Though studies have attempted to bring the individual stakeholder's perception over the contestation, the analysis have not been drawn from the state restructuring perspective. Moreover, the new power dynamics and its implications in resolving the contestation still remains unexplored.

This article broadly discusses the motive behind the evolution of such contestation and its potential consequences in the federal governance system of Nepal within the three-elements of conflict approach discussed by Brown et al. (2017). This analysis is anticipated to contribute to better understanding of resource conflict scenario in the context of Chure landscape conservation and management and to trace out the potential roles of the newly formed and elected governments, on sustainable management of Chure landscape in Nepal.

\section{METHODOLOGY AND ANALYTICAL FRAMEWORK}

The issues around Chure landscape and its forest management are broadly associated with 'a complex and multiple set of underlying causes' (Bishwokarma et al. 2016). It is essentially associated with broader political, social, economic, and ecological contexts. Thus, the understanding on the contestati on around Chure forest management and options to resolve it varies among the stakeholders. This paper employs three elements of conflict approach (Figure 1), a) the location of resources, b) stakeholders, and c) perceived consequences, in order to understand and analyse the contestation on Chure landscape and its forest management.

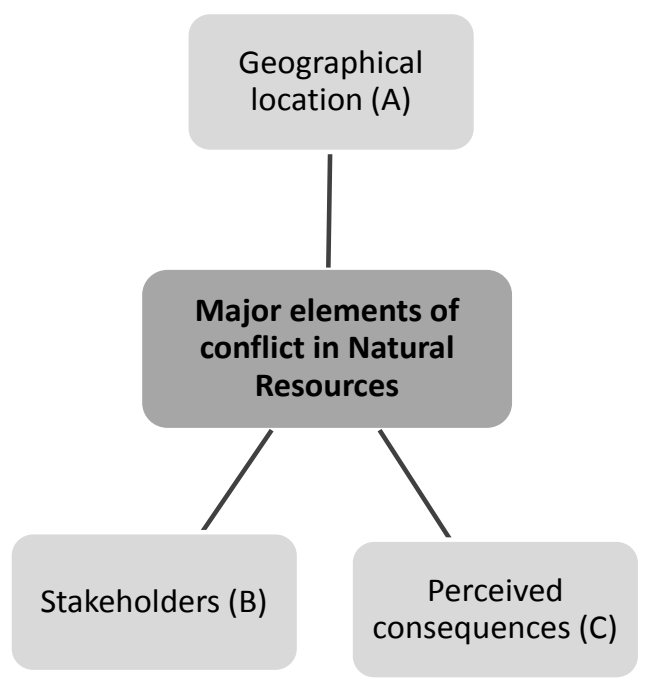

Figure 1: Elements of Conflict (Adapted from Brown et al. 2017) 
The study employs a multi-layer approach in collecting the empirical data. Primary data were collected from expert interviews at the national level, and key informant interviews and focus group discussions were held at the community level. At the national level, five informal meetings with different stakeholders - both government and non-government actors - were carried out. These meetings helped in validating the information collected from the field. Five CFUGs from Chitwan and Bara districts were visited during April and July 2017 to conduct key informant interviews. About 10 and 12 key informants were interviewed in Chitwan and Bara respectively in order to understand the community perceptions on Chure contestation in the changed political context. Moreover, the recently elected local government leaders from both districts were consulted to understand their position regarding Chure landscape management. Review of relevant literature around Chure landscape management and the (first) authors' personal engagement at local, district, and national level events organised by various Civil Society Organisation (CSOs) and the Chure Board has complimented the analysis.

\section{CHURE AND CONFLICT}

Chure landscape is the youngest and one of the most fragile landscapes of Nepal extending from East to West between Terai and Hill covering about 12.8 per cent of the total land area and harbouring about 14 per cent of the total population (DFRS 2014). About 72.37 per cent of its area is forest land that offer habitat for various ecosystems and significance for timber and mining (Bishwokarma et al. 2014; DFRS 2014). In addition, it serves as a biological corridor for wild animals, some of which includes charismatic species (DFRS 2014). Similarly, rivers originated from Chure hills have a crucial hydro-ecological function both within the region and down-stream. It is considered as a lifeline for down-stream communities, specifically for water sources, while inhabiting millions of poor and rural population that are dependent on available natural resources. Moreover, it also contributes to develop linkage between upstream and down-stream relationship between people living in Chure range and people living in Terai, including flood and sedimentation reduction in the downstream and providing food from forest commons to nourishing their family.

Chure forests are being managed under different management regimes. A large section of these forests is managed and controlled by the government (Pokhrel 2013; DFRS 2014). Out of the government controlled forests, 24 per cent falls under the Protected Area management system (DFRS 2014). On the other hand, some parts of the Chure forests are handed over to the local communities as CFs. Records from the Department of Forest (DoF 2018) show that a total of 490,547 household members are engaged in Chure forest management through 2,837 CFUGs. However, the Federation of Community Forest Users Nepal (FECOFUN) claims that the total number of CFUGs is about 4,000 (Bishwokarma et al. 2014). Moreover, local communities are protecting and managing some forests as leasehold forest and collaborative forest though it is very insignificant in terms of area.

Literature have claimed that community managed patches of forest are performing better than the government managed 
forests, though there are still number of issues primarily associated with management and governance (CSRC 2007). Forests managed by the government are indeed under extreme pressure as it doesn't involve any systematic and active forest management practices and is de facto open access for communities residing near the forests. As a result, deforestation and unsustainable extraction of sand, gravels, and boulders (SGB) remains uncontrolled (Bampton et al. 2007). Similarly, there is also an increasing interest of selected stakeholders in timber harvesting for commercial purposes, but largely through illegal routes (Bhattarai et al. 2002).

In the last decade, forest management in Chure has remained contested. The media reports have mainly highlighted rampant deforestation and degradation of Chure forests, specifically from illegal logging and heavy extraction of SGB, and emphasised on the failure of effective implemention of the 'President-Chure Conservation Programme'. Similarly, the argument of Terai population has contradicted with that of the hill population. Due to increasing water scarcity, siltation, and loss of human lives and properties from disasters in the down-stream, inhabitants in Terai have further stressed on taking step towards effective management of Chure forests and its landscape. Media coverages and constant pressure from Terai community have dragged the attention of political leaders and the government at the national level, and has led government to declare the Chure region as an $\mathrm{EPA}^{1}$ on June
2014, under the Environment Protection Act (1997) (See Bishwokarma et al. 2014 and 2016). This has been followed by the establishment of the powerful 'Chure Board' under the Development Board Act (2013). However, communities residing in Chure were not adequately consulted. In fact, a majority of households residing in Chure does not have land entitlements (DFRS 2014) as they have migrated from other parts of Nepal, especially from the hilly districts and are therefore heavily dependent on forests and daily wage-based activities including collection of SGB. This has mislead the policy-stakeholders including forest administrators to interpret local communities as the main culprits for deforestation and landscape degradation (Bishwokarma et al. 2014). This understanding has catalysed statecommunity contestation.

The Chure Board has been formed with the primary objective to plan and implement Chure management interventions so as to achieve its management and conservation goals. However, stakeholders perceive that there has been a rather top-down approach to Chure management, primarily through mobilisation of Forest and Soil Conservation authorities. Moreover, imposition of stringent measures including ban on harvesting of green trees has had negative impression among the stakeholders. In fact, the declaration of EPA and the formation of Chure Board has raised speculations among the stakeholders on re-centralisation of power which in turn has triggered mistrust and contestation between the government and CFUGs.

\footnotetext{
1 The government declared Chure as EPA based on Environment Protection Act 199710 (1) which says: "Government of Nepal may, by a notification in the Nepal Gazette, maintain any place within Nepal containing natural heritage or aesthetic, rare wildlife, biological diversity, plant, and places of historical and cultural importance, which are considered extremely important from viewpoint of environment protection, as an Environment Protection Area."
} 


\section{STAKEHOLDERS,}

PERCEPTION AND INTEREST ON CHURE MANAGEMENT

\section{Major Stakeholders and Role in Chure Management}

The Chure region is politically dynamic mainly due to the fact that there are a range of stakeholders, with varied interest and roles involved (table 1). The government is mainly developing and enforcing policies for Chure forests and landscape management. Besides, it also grants permission to extract SGB though there are divergent views across the

Table 1: Major Stakeholders and Role on Chure Management

\begin{tabular}{ll}
\hline $\begin{array}{l}\text { Major } \\
\text { stakeholders }\end{array}$ & $\begin{array}{l}\text { Major role on Chure } \\
\text { management }\end{array}$ \\
\hline Government & $\begin{array}{l}\text { Policy development and } \\
\text { enforcement; provide } \\
\text { license and approval for }\end{array}$ \\
SGB extraction \\
Donors & $\begin{array}{l}\text { Technical assistance and } \\
\text { funding }\end{array}$ \\
Forests user & Represent local users and \\
based federations & advocacy for their rights; \\
and networks & $\begin{array}{l}\text { engage on policy process } \\
\text { Work with the }\end{array}$ \\
Other CSOs & $\begin{array}{l}\text { government, federations, } \\
\text { and local users to } \\
\text { contribute on their } \\
\text { activities }\end{array}$ \\
Engage on policy \\
process; solidarity on \\
advocacy \\
leaders
\end{tabular}

different Ministries. For instance, Ministry of Forest and Soil Conservation (now Ministry of Forest and Environment), and Ministry of Finance were at odds on the decision to allow extraction of boulders, sand and stones from Chure in 2015. While the District Forest Office (DFO) provides permission for timber extraction, different forest user-based federations and networks representing local communities, broadly advocate for users' right. Similarly, donor agencies provide fund and technical support to the government on various initiations while the CSOs contribute to both government initiatives and local people's welfare while working with the federations and local communities. In addition, the major political parties and their leaders engage on both policy process and advocacy for community rights pertinent to the issues of Chure. Among others, local communities of Chure have an important stake as they remain at the fore-front in conservation, management, and utilisation of forest resources. The private sector, though not directly engaged in the management of Chure, is an equally influential stakeholder as it involves timber and SGB extraction, which is understood to be the main factor of Chure degradation.

\section{Stakeholders' Response on EPA Declaration}

The government decision to declare Chure landscape as an EPA has clearly divided stakeholders into two groups: one opposing the government's decision and the other supporting it (table 2). The rightbased stakeholders led by the FECOFUN have shown their outright disagreement on the government decision and decided to protest against it. Various stakeholders, mostly advocating for community 
rights on forest resources, have united and staged series of protest events such as rally at district and national level, and held several interactive workshops, not only as a strategy to pressurise the government but also to communicate on potential consequences of those decisions on community rights. A central member of FECOFUN expressed his concern on Chure in the following way;

The governments' decision to declare Chure as an Environmental Protection Area without proper consultation with local communities and other stakeholders has shown its interest to re-centralise power to the government. This decision does not solve the Chure problem, instead curtails the community right over forest resources.

\section{Box 1: Changes on CF Operational Plan in Chure after EPA}

- Divided forest area into blocks specifically based on 'hot spots' for biodiversity conservation,

- Suspended annual allowable cut (AAC),

- Followed the concept of 'limited use zone' and 'physical rotation'; no green felling; no harvest for commercial purpose.

Table 2: EPA Declaration and Three Elements of Conflict in Chure Forest Management

\begin{tabular}{|c|c|c|c|}
\hline \multirow{2}{*}{$\begin{array}{l}\text { Geographic } \\
\text { location (A) }\end{array}$} & \multirow{2}{*}{$\begin{array}{l}\text { Major } \\
\text { Stakeholders (B) }\end{array}$} & \multicolumn{2}{|l|}{ Perceived consequences (C) } \\
\hline & & & $\begin{array}{l}\text { Stakeholder } \\
\text { decision }\end{array}$ \\
\hline $\begin{array}{l}\text { - Extending } \\
\text { from East to } \\
\text { West covering } \\
12.8 \text { per cent } \\
\text { of the total } \\
\text { area of the } \\
\text { country } \\
\text { - Fragile } \\
\text { landscape but } \\
\text { hotspot for } \\
\text { biodiversity } \\
\text { - Source of } \\
\text { revenue } \\
\text { mainly from } \\
\text { quarrying } \\
\text { stone, } \\
\text { boulder, and } \\
\text { sand }\end{array}$ & $\begin{array}{l}\text { - } \text { National } \\
\text { Government } \\
\text { /Relevant } \\
\text { Ministries } \\
\text { - Political Parties/ } \\
\text { leaders } \\
\text { - Federation of } \\
\text { Forest Users } \\
\text { - Political ideology } \\
\text { based unions of } \\
\text { techno-bureaucrats } \\
\text { - Different CSOs } \\
\text { - Local Forests } \\
\text { Users (CF, } \\
\text { CFM,etc.) } \\
\text { - Local government } \\
\text { - Down-stream } \\
\text { communities } \\
\text { - Private sectors }\end{array}$ & $\begin{array}{l}\text { - Reduce forest and } \\
\text { landscape degradation } \\
\text { - Regains overarching } \\
\text { management power } \\
\text { - No compromise on } \\
\text { local users' right } \\
\text { - Addresses public } \\
\text { interest in the down- } \\
\text { stream } \\
\text { - Contributes to } \\
\text { maintain and/or } \\
\text { expand institutional/ } \\
\text { political legacy at } \\
\text { national and down- } \\
\text { stream } \\
\text { - Reduces hazards and } \\
\text { hence loss of lives and } \\
\text { properties }\end{array}$ & $\begin{array}{l}\text { - Doesn't contribute } \\
\text { to address the real } \\
\text { problem of Chure } \\
\text { - Curtails users' right } \\
\text { and access to forest } \\
\text { resources } \\
\text { - Loses institutional } \\
\text { legacy in the region } \\
\text { and national level } \\
\text { - Negative impacts } \\
\text { on local livelihood } \\
\text { - Establishes } \\
\text { negative role of } \\
\text { local users on } \\
\text { Chure degradation }\end{array}$ \\
\hline
\end{tabular}




\section{EPA Declaration and \\ Stakeholders' Interest: Opposing Consortium}

The stakeholders who are against the decision of the government have three differing perceptions against the EPA declaration. First, the Chure decision curtails community rights over forest resources. The local communities are comparatively independent to make their decision on forest conservation, management, and utilisation through CFUG as per the provision of Forest Act 1993 and Forest Regulations 1995. Forest management through CF has been successful and has demonstrated in various accounts. However, right-based stakeholders are skeptical about the government's intention on re-possessing forests as Protected Areas that have already been handed over to the local communities. Moreover, stakeholders are cynical on limiting community rights and imposition of protection-centric provisions through declaration of EPA. One of the members of the opposing stakeholders' ally expressed;

We definitely support the initiatives of Chure conservation. However, the role and effort of local communities have to be well-recognised, ensuring their livelihood options and right to forests resources

The Chure forests and landscape management activities so far under the supervision of Chure Board have demonstrated that decentralisation of forests management under CF limits their rights. Hence, the local communities have experienced curtailment of their rights over forests as explained by a CFUG leader in Chitwan;
We have felt that CFUGs are not as autonomous as before [the declaration of EPA] to make their decision on forests management and utilisation. We are told to ban harvesting of green trees as per our operational plan and implement conservation related activities only. It clarifies that we will not be able to plan and implement scientific forests management activities in our CF.

Second, the stakeholders perceive that the declaration of EPA that has limited community rights over forest resources is an outcome of mis-understanding of Chure issues. One of the major issues pertinent to Chure degradation is the uncontrolled use of heavy equipments for quarrying of SGB. It has catalysed natural hazards such as flooding, siltation and landslide, infrastructure damage and loss of human lives and properties within the region and down-stream. The government issues permit to private sectors for quarrying SGB, however the blame for uncontrolled quarrying is rather directed to local communities. The agitating stakeholders, hence, argue that the government decisions are less likely to address the actual problems as stated by a member of a CSO;

The major reason of Chure degradation is uncontrolled quarrying of sand, stone, and gravel using heary bulldozers. The government provides the permit and contracts out to private parties. Local people simply work for daily-wages. Instead of blaming local communities, the government should stop providing permission to quarry using bulldozers.

Third, the stakeholders perceive that the declaration of EPA potentially (de) limits the scope of community based organisations (CBOs) and role of $\mathrm{CSOs}$ 
in terms of access and control over the resources. Most of the criticism comes from the right-based CSOs who are advocating for community rights over forest resources, specifically through CFs. There are thousands of CFUGs in Chure region who are members of their network. After the declaration of EPA, those CFUGs keep questioning the role of their network. This may compromise the stake of maintaining existing institutional legacy for those right-based federations and network, as expressed by a forestry expert during a consultation meeting in Kathmandu.

CFUGs will definitely be bolding its network/federation to account while compromising the community rights over forests resources because of the EPA declaration. It will definitely put more pressure and risk of compromising its existing institutional legacy. Potentially, it has also compelled rightbased organisations to unite against the government decision [to declare Chure as an EPA]

\section{EPA Declaration and Stakeholders' Interest: Supporting Consortium}

Despite the rejection of the government's decision by some stakeholders, others considered it to be a milestone in terms of addressing issues around Chure forests and landscape management. The members of CSOs and stakeholders who are basically located in the southern part of the Chure region, working with the government agencies and/or working with experts, have appeared to be supporting the government decisions. Though, the ones in the favor of government decision were less active than those opposing it, they also have shown their stance through press releases, and interaction during events organised by themselves and the government. Moreover, these stakeholders have been utilising means of social networks including Facebook to express their solidarity and communicate their stance.

The stakeholders supporting the government decision have multiple interests in the declaration of Chure forests as an EPA. They primarily hold three different perceptions. First, they state that the declaration of EPA and formulation of Chure Board will control the degradation of Chure landscape. The powerful Chure Board is responsible for planning and implementation of Chure conservation and management activities, mainly coordinating different government agencies within the Ministry of Forests and Environment (MoFE) as stated on its website;

As the work of Chure conservation is related with multi facets, multisectoral, and multi-stakebolders, to run it in a coordinated and effective way the Nepal government enacted President Chure-Terai Madhesh Conservation Development Board (Formation) Order $2071^{2}$.

Second, some bureaucrats perceived that they should have more power to plan and implement conservation and management activities to control degradation. The decision, hence could rejuvenate the bureaucratic power on Chure forest management. However, in response to agitating stakeholders, the Chure board has promised to guarantee collaborative implementation for conservation activities with local communities and relevant stakeholders as stated by a member of the Chure board;

\footnotetext{
${ }^{2}$ http://chureboard.gov.np/en/?p=10, accessed on 11 March, 2018
} 
Chure degradation is a widely accepted issue and hence needs proper and planned conservation and management interventions. However, we are committed to ensuring existing community rights over forest resources. We also would like to ensure to collaborate with local communities to implement all conservation activities in Chure, which we have been doing after formation of the [President Chure-TeraiMadhesh Conservation Development Board] board.

The government has attempted to ensure agitating stakeholders to have community rights and employ participatory approach. This promise was communicated to communities through a number of press releases, notices, and expression of commitment in various public events.

Third, some stakeholders have anticipated to extend their institutional and political legacy at the national level and in the down-stream communities. Some political leaders perceived that the government decision would potentially contribute to reduce Chure degradation so as to address different impacts in the down-stream, including water scarcity and loss of lives and properties from natural disaster. They anticipate that it will strategically contribute to maintain political legacy in the down-stream. However, some community users network, mostly based in the down-stream, have perceived that they could potentially expand their institutional legacy and policy process at national level after supporting the government decision. A central member of the association of Collaborative Forests opined;
We welcomed and supported the government decision as it will support conservation and sustainable management of Chure, Terai, and Madesh. This effort will give an opportunity to the down-stream community to take part in conservation activities so as to conserve their productive land of Terai.

Stakeholders have been arguing that the government decision manifests a top-down approach to policy intervention despite experiencing failure of such practices in the past. It is essentially informed by the biophysical aspects of Chure degradation despite association of other socioeconomic elements which triggered the government and local actors contestation, especially CFUGs (Bishwokarma et al. 2014). Addressing the biophysical aspect is undoubtedly important, but needs to respect the social construction of the upstream and down-stream communities as one former forest official stressed;

There is a need for an innovative framework on participatory natural resource management in Chure. The participatory resource management approach at watershed level could be an option which could link people in the up-stream and down-stream.

\section{CONTINUED CONTESTATION AND POWER RELATION}

Contestation over Chure has been followed by rejection of the decisions made at various periods. Some of the stakeholders, specifically those opposing EPA declaration, have challenged and questioned the state's efforts and achievements on conservation despite huge financial investment in the Chure forest 
and landscape conservation. Despite wider acceptance on the urgent need for intervention in Chure conservation, the government's decision to declare the Chure region as an EPA has broadly divided stakeholders. However, the observation oppoising reveals that the actors within those two opposing groups have clear interests of strengthening their power-relation. As Bourdieu (1985) argues, actors in the social world attempt to create their comfortable space based on their principles of differentiations. Therefore, stakeholders in Chure have responded to the government's decision by hoping to maintain their power-relation (Figure 2).

The stakeholders mostly agree that the government decision was enacted without adequate consultation. Clear division of those stakeholders has been seen, primarily anticipating to balance the power-relation among them. The government itself has arguably made the decision using its hegemonic ${ }^{3}$ power even without proper consultation with the local communities and stakeholders - the frontline and most impacting stakeholders. It clearly intends to maintain the power-relation in the forestry sector and beyond, through three objectives as an outcome of the decision. First, the government intends to address the pressure from down-stream population to initiate urgent action to control Chure degradation. Second, it planned to create a national entity so that it can address the issues and challenges of Chure. Third, it was expected to reduce the degradation through overarching planning and management. Moreover, the decision somehow is driven by the aim to maintain authority by imposing the EPA.

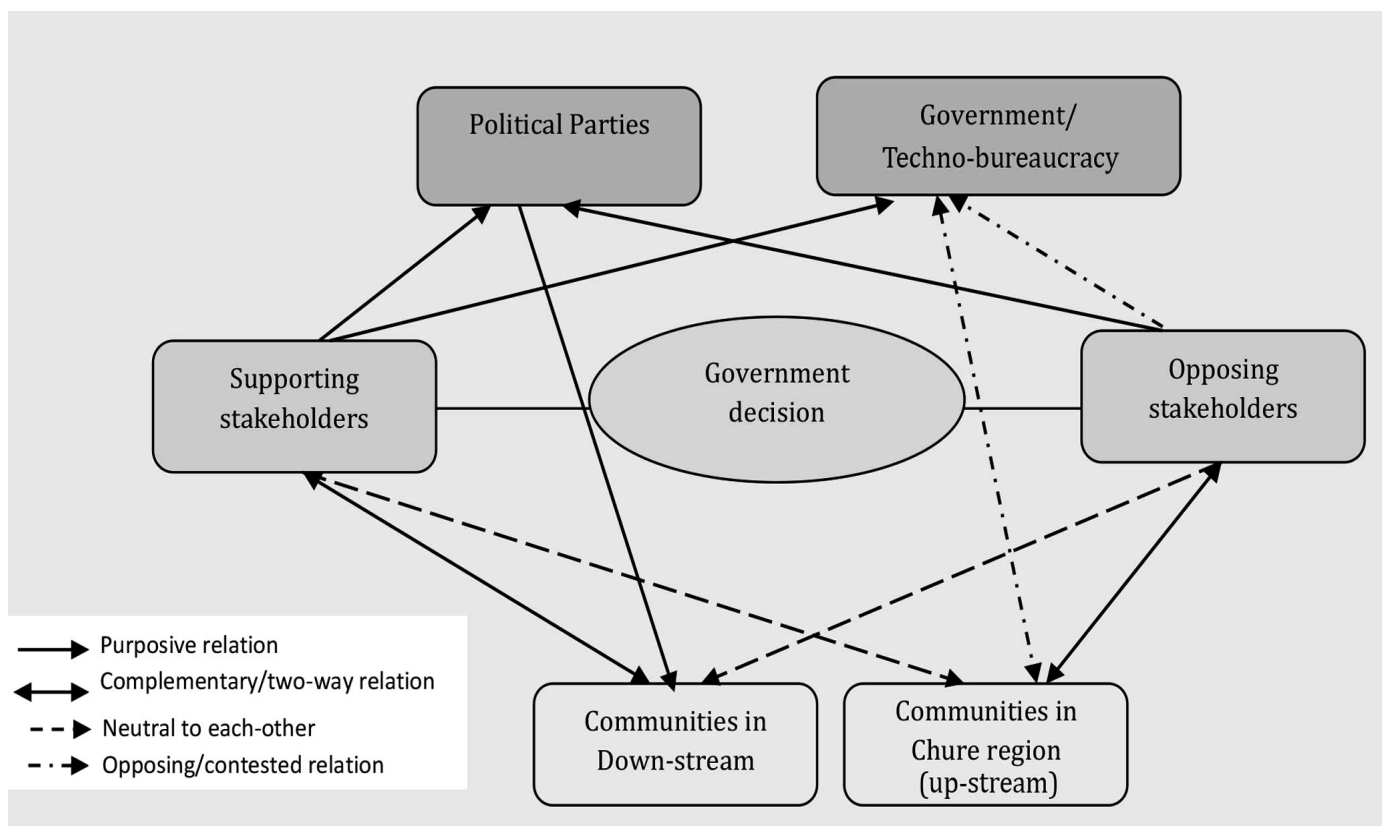

Figure 2: Stakeholders and Power-Relation Network in Chure Region

${ }^{3}$ The term 'hegemony' used in this article as 'process dominance while making decision on Chure conservation'. It is based on the 'theory of hagemoney' (Bates 1975). 
A majority of the opposing stakeholders intend to maintain the power-relation at policy level through continuing and strengthening relations with local communities as well as opposing political parties. Most of the opposing stakeholders led by FECOFUN are the federations and networks. The strength and power of such stakeholders is strategically demonstrated through protest-rallies, as stated by a participant during a consultation meeting

(19 November 2017);

We have mobilised thousands of local people to protest against the government decision in Chure. We do have the ability to mobilise even more people and will continue to do so until the government comes to consensus.

Additionally, the nature of contest of the FECOFUN led consortium is more community - centric, considering $\mathrm{CF}$ as the only option to address issues around Chure. The more forests area in Chure is handed over to local communities as CF or Collaborative Forest Management (CFM), the less area remains under the government management. The collective action and advocacy for community rights in Chure has strengthened power-relations with their members and has shown a strong presence at the policy level. Yet, the government decision has placed the state and communities as opposing actors in terms of their power-relation, considering the potential curtailing of community rights over forests resources.

In contrary, the stakeholders supporting government's decision also see an opportunity to take advantage of the heterogeneity within the ally members to improve and strengthen their power-relation. They perceive that the government should make stringent decisions so that they could maintain their influence in Chure, as stated by a forest officer based in Bara;

We need strong government decision and enforcement mechanism so that the law enforcement body could punish the people involved in [Chure] degradation. Government should have the right to make the Chure management decision rather than being influenced by so called advocacy organisations.

Likewise, some of the ally members of both agitating groups have been echoing in support of, or opposite to, government decision in strengthening power-relation with certain political parties so as to establish their institutional legacy at the national as well as local level, mainly in the down - stream. Interestingly, the politicalideology based agitating groups have been following their respective political streams so that they could strengthen their nexus and power-relation. However, all ally members intend to maintain good relations with down-stream communities in order to strengthen their power-base.

Three years following the enforcement of the government's decision on Chure, contestations appear to have largely reduced, though certain level of misunderstanding among stakeholders still persists. Three years down the lane, Chure no longer remains a priority issue in the forestry sector, while other political agenda has dominated the discourse. A senior forest official at the Ministry of Forest and Environment (MoFE) stresses on new priorities in the changing context; 
I believe, the [Chure] board is not relevant after the country enters into the federal system. Even if it remains, it should be restructured in such a way that could include different agitating stakeholders to resolve their issues and get cumulative effort on reducing the Chure degradation.

With change in the power relations along with the newly elected governments at local, provincial, and central levels, the government will potentially have some changes in the power dynamics in Chure and contestations surrounding it. There are also strong voices in support of local communities and re-orientation of Chure where one of the Members of the Provincial Parliament expressed his strong commitment in providing maximum right to the communities and will continuously advocate for it.

\section{FEDERALISATION AND RESOLUTION ON CHURE}

Contextualising the concept of Brown et al. (2017), contestation in Chure can be attributed to three major elements: geographical location, stakeholders, and perception on results. The first element remains static, with multiple level of bio-physical, cultural, and socioeconomic significance. Yet, efforts are still required to address issues raised by the stakeholders. Series of consultations at local and central levels regarding the potential options to resolve the ongoing state-community tensions reveal that interactive conflict management approach can help in balancing the powerrelations among stakeholders and can potentially create a win-win situation. A balanced power relation could be attained ensuring procedural justice to stakeholders including local communities (Leach et al. 2010), primarily ensuring opportunities to meaningful participation of stakeholders on Chure management policy and implementation process. Indeed, the opposing stakeholders have been strongly demanding for participatory and transparent decision-making process rather than imposing a centralised approach to Chure management. Intensive participation and discussion among stakeholders would then contribute to understanding Chure degradation from multiple dimensions. It would bring transparency on the decision-making process and contribute to resolving the contestation.

Second, a customised management approach has to be identified based on learnings from failures of centralised state power practice and successful experiences of participatory approach. A blanket approach to Chure management may not be effective due to the fact that forest degradation is not only a result of a single factor. A 'watershed based approach' does not only link upstream and down-stream communities to collaborate and equally contribute to Chure management but also prioritises specific interventions engaging stakeholders. Among limited scholarly contributions, a few have also highlighted such interventions (for example see Singh 2012) in order to bring a synchronised response more efficiently.

Revision of the structure of Chure board in order to offer space for more actors would be another strategy in addressing the contested issue in the region. Due to the political nature of the Chure board, there always remains a question on engagement of stakeholders and communities beyond the political boundary. This has been 
widely criticised and raises questions on governance and inefficiency to achieving anticipated objectives of reversing degradation in Chure.

With the inception of federalist governance structure, the local government has been delegated with the power to prepare and implement local policies and plans. According to the Constitution of Nepal 2015, and Local Government Operation Act 2017, the local government can carry out activities involving local market management, environment protection and bio-diversity and protection of watersheds, wildlife, mines and minerals. Utilising these powers, local governments could fix the rates for sale and revenue of natural resources including SGB, and develop and implement local policies on environment protection and biodiversity conservation. This also implies that the role for management of Chure could be delegated to the local government. So, the newly elected governments, specifically at the local and provincial levels, could proactively play the role of local negotiators by establishing a strong and sustainable network between neighboring local governments. This would not only allow the engagement of all relevant stakeholders but would also introduce customised management initiatives such as 'watershed based management approach'.

Secondly, the newly elected members of the local governments have diverse experiences on natural resource management. Some were leading the advocacy campaign for community rights to local people as part of the 'opposing' ally. Likewise, some were supporting the EPA declaration. Their previous experiences could contribute to better understanding of the Chure issues from multiple dimensions and facilitate conflict resolution process. The role of the local and federal governments will also be crucial in practicing a widely discussed and demanded bottom-up approach regarding planning and implementation. This is a good opportunity to build trust at community level and bridge the trust-gap between the State and local communities in management of Chureforests and landscape. However, there is always a risk of intralocal government conflicts regarding their respective divergent interests and decisions on resource management. Therefore, this calls for a careful engagement of and coordination among stakeholders in effective management of Chure region.

\section{CONCLUSIONS}

This paper presents the significance of Chure landscape and stakeholder involvement on its management. Considering the ecological and geo-political significance, different stakeholders are interested to, and engage in, Chure management. There has been a wider consensus on the ongoing degradation of Chure forest and landscape and need for urgent priorities to control it. However, there are strong differences in terms of understanding the underlying causes of degradation as well as the potential solutions. The government decision to declare Chure as EPA is perceived as the manifestation of such differences and the crux of state-community contestation. We described ongoing contestation on Chure forests and landscape management based on three-elements of conflict approach, a) the locations of resources, b) stakeholders, and c) perceived consequences. Our analysis revealed that declaration of EPA has invited statecommunity contestation mainly due to differences on the perceived consequences. 
The government decision on enacting EPA is mainly based on the biophysical aspects of Chure, yet, it doesn't take into account its socio-economic aspects. This has led to exclusion of some stakeholders in the decision-making process and is argued to have curtailed community rights over forests resources.

Contestation in Chure is fueled by polarised institutional and political interest of stakeholders. With differences in their opinion, the government's policy decision and opposing responses of the stakeholders are mostly aimed at strengthening their power-relations rather than solving the problem of Chure degradation. We argued that the existing contestation will not be resolved without ensuring CFUGs' rights, enhancing community' access to forests resources, and balancing power relations among stakeholders. Four different options could potentially contribute to the resolution of contestation in Chure. First, the power-relation could be ensured on Chure management through procedural justice offering opportunities of participation to all stakeholders including citizens' associations as well as ensuring transparency in decision-making. Second, up-stream and down-stream linkage could be established introducing special approach of resource management such as 'watershed-based management'. Third, the recently elected local and provincial governments could play an active role in negotiating with the conflicting parties and come to a consensus. Finally, revisiting role of the Chure Board on both policy formulation and implementation could offer a balanced power relation among stakeholders. A more unwavering and inclusive Chure Board could offer procedural justice to stakeholders and hence lead to resolve the ongoing contestations.

\section{ACKNOWLEDGEMENT}

We would like to acknowledge number of stakeholders and local community forest users in Bara and Chitwan districts for offering their time and providing information.We are thankful to the peer reviewers and the editorial team of the Journal of Forest and Livelihood for their continuous support.

\section{REFERENCES}

Andersson, K.P. and Ostrom, E. 2008. Analyzing Decentralized Resource Regimes from a Polycentric Perspective. Policy Sciences, 41(1): 71-93.

Bampton, J.F.R., Ebregt, A. and Banjade, M.R. 2007. Collaborative Forest Management in Nepal's Terai: Policy, Practice and Contestation. Journal of Forest and Livelihood, 6(2): 30-43.

Banjade, M.R. 2012. Discourse and Discursive Parctices over Timber in Nepal. Journal of Forests and Livelihood, 10(1): 58-73.

Bates, T.R. 1975. Gramsci and the Theory of Hegemony. Journal of the History of Ideas, 36 (2): 351-366.

Bhattarai, K., Conway, D. and Shrestha, N.R. 2002.The Vacillating Evolution of Forestry Policy in Nepal: Historically Manipulated, Internally Mismanaged. International Development Planning Review, 34: 315-338.

Bishwokarma, D., Thing, S.J. and Paudel, N.S. 2016. Political Ecology of the Chure Region in Nepal. Journal of Forest and Livelibood, 14(1): 84-96.

Bishwokarma, D., Paudel, N.S. and Thing, S.J. 2014. Policy-Practice Gap on Chure Management: Analysis of Chure Policy Implications on Community Right on Forest Resources. Right and Resources Initiatives (RRI) and ForestAction Nepal, Kathmandu, Nepal. 
Bourdieu, P. 1985. The Social Space and the Genesis of Groups. Theory and Society, 14(6): 723-744.

Brown, G., Kangas, K., Juutinen, A. and Tolvanen, A. 2017. Identifying Environmental and Natural Resource Management Conflict Potential Using Participatory Mapping. Society E Natural Resources, 30(12): 1458-1475.

Cilliers, P., Biggs, H.C., Blignaut, S., Choles, A.G., Hofmeyr, J.S., Jewitt, G.P.W. and Roux, D. J. 2013. Complexity, Modeling, and Natural Resource Management. Ecology and Society, 18(3): 1.

Collier, P. 2003. The Market for Civil War. Foreign Policy, 136: 38-45

CSRC. 2007. Charbroiled Chure. Community Self Reliance Centre, Kathmandu, Nepal.

DOF. 2018. Community Forestry Data Base. Deprtment of Forests, Government of Nepal, Kathmandu, Nepal.

DFRS. 2014. Churia Forests of Nepal (2011-2013). Forest Resource Assessment Nepal Project/ Department of Forest Research and Survey, Government of Nepal, Kathmandu, Nepal.

Humphreys, M. 2005. Natural Resources, Conflict, and Conflict Resolution. Journal of Conflict Resolution, 49(4):508-537.

Leach, M., Scoones, I. and Stirling, A. 2010. Dynamic Sustainabilities: Technology, Environment, Social Justice., London and Washington DC: Earthscan.

Michon, G., Nasi, R. and Balent, G. 2013. Public Policies and Management of Rural Forests: Lasting Alliance or Fool's Dialogue? Ecology and Society, 18(1): 30.
Ojha, H., Timsina, N. and Khanal, D. 2007. How are Forest Policy Decisions Made in Nepal? Journal of Forests and Livelihood, 6(1): 1-17.

Pokhrel, K.P. 2013.Chure Forestry Conservation and Management Plan: A Case Study of Arghakhanchi District, Nepal. Journal of Geography and Regional Planning, 6(5): 172183.

Ratner, B.D., Burnley, C., Mugisha, S., Madzudzo, E., Oeur, I., Mam, K., Rüttinger, L., Chilufya, L.N. and Adriázola, P. 2017. Facilitating Multistakeholder Dialogue to Manage Natural Resource Competition: A Synthesis of Lessons from Uganda, Zambia, and Cambodia. International Journal of the Commons, 11(2): 733-753.

Schusser, C., Krott, M., Movuh, M.C.Y., Logmani, J., Devkota, R.R., Maryudi, A. and Salla, M. 2016. Comparing Community Forestry Actors in Cameroon, Indonesia, Namibia, Nepal and Germany. Forest Policy and Economics, 68: 81-87.

Singh, B.K. 2012. Social Inclusion/ Exclusion of River- Affected Down-stream People in Conservation and Management of Fragile Churia Hill: Linking Upstream and Downstream from the Perspective of Environmental Services $\mathrm{PhD}$ Dissertation, Institute of Forestry, Tribhuvan University, Nepal. 